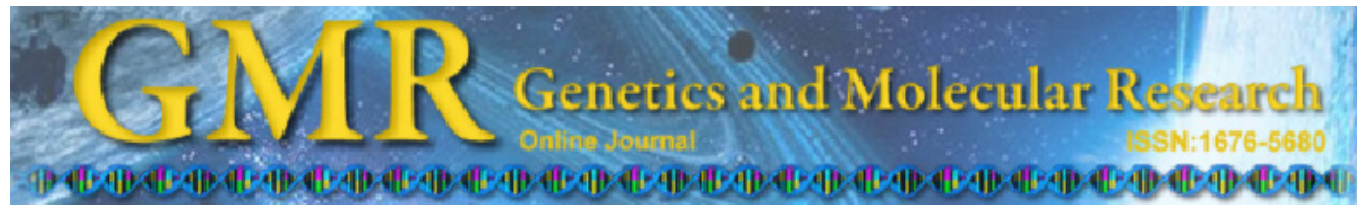

\title{
Molecular response of human cervical and lumbar nucleus pulposus cells from degenerated discs following cytokine treatment
}

\author{
J.Y. Park, Y.S. Yoon, H.S. Park and S.U. Kuh \\ Department of Neurosurgery, Spine and Spinal Cord Institute, \\ College of Medicine Gangnam Severance Spine Hospital, \\ Yonsei University, Seoul, Korea \\ Corresponding authors: S.U. Kuh / Y.S. Yoon \\ E-mail: kuhsu@yuhs.ac/ysyoon@yuhs.ac
}

Genet. Mol. Res. 12 (1): 838-851 (2013)

Received December 5, 2012

Accepted February 20, 2013

Published March 15, 2013

DOI http://dx.doi.org/10.4238/2013.March.15.4

\begin{abstract}
We investigated the molecular response of degenerated human cervical and lumbar nucleus pulposus (NP) cells following cytokine treatment. Degenerated cervical and lumbar discs $(8$ each) were obtained from patients who underwent discectomy for degenerative disc disease; NP cells were isolated and cultured. The mRNA expressions of aggrecan, alkaline phosphatase, type I collagen, type II collagen, osteocalcin, and Sox 9 in the 2 groups were compared by real-time PCR, before and following treatment with rhBMP-2 and TGF- $\beta 1$. Immunoreactivity was analyzed to check protein activity. Type I collagen expression was significantly higher in cervical compared with that in lumbar disc cells. The mRNA expression was significantly increased after rhBMP- 2 and TGF- $\beta 1$ treatment. After rhBMP-2 treatment, mRNA expression of type I and II collagens increased significantly more in cervical than in lumbar NP cells. Following TGF- $\beta 1$ treatment, the increase in mRNA expression was not significantly different between cervical and lumbar disc cells. Protein immunoreactivity, before and after cytokine treatment was similar to mRNA expression data. The matrix-related gene expression of cervical
\end{abstract}


and lumbar NP after rhBMP-2 and TGF- $\beta 1$ treatment increased similarly, with the exception of collagen expression.

Key words: Aggrecan; Alkaline phosphatase; Collagen; Osteocalcin; rhBMP-2; TGF- $\beta 1$

\section{INTRODUCTION}

The pathogenesis of intervertebral disc degeneration is a complex process that disrupts the well-defined organizational and biochemical balance due to replacement of the normal disc matrix by more fibrotic, less cartilaginous material (Antoniou et al., 1996a,b; Evans, 2006; Peng et al., 2006; Yoon and Patel, 2006; Kuh et al., 2009; Park et al., 2011). Disc degenerative changes can be associated with pain, and treatment options are limited. Many trials of potential molecular and biological therapies have been conducted in this context. Previous studies have evaluated 3 main biochemical changes in disc degeneration: 1) decreased matrix synthesis, 2) increased catabolism, and 3) change in growth factors and cytokines associated with altered disc cell phenotypes during aging and degeneration (Diefenderfer and Brighton, 2000; Tim et al., 2003; Yoon and Patel, 2006; Zhao et al., 2007; Fassett et al., 2009; Kuh et al., 2009). Of the various genes associated with matrix synthesis, type I and type II collagens (fibrillar molecules), aggrecan (consists of a core protein to which sulfated-glycosaminoglycans are attached), Sox9 (upregulates both aggrecan and type II collagen), osteocalcin, and alkaline phosphatase (markers of osteogenic genes) are important (Adam and Deyl, 1984; Diefenderfer and Brighton, 2000; Tim et al., 2003; Kuh et al., 2009).

To reverse the degenerative changes by altering disc matrix metabolism, many investigators have attempted molecular therapies, including the use of cellular components, matrix derivatives, and molecules influencing disc cell metabolism and phenotypes (Tim et al., 2003; Yoon et al., 2004; Seguin et al., 2005; Weiler et al., 2005; Yoon and Patel, 2006; Evans, 2006; Fei et al., 2006; Kuh et al., 2008; Park et al., 2011). Previous molecular therapy trials were typically conducted on lumbar discs (Tim et al., 2003; Yoon et al., 2004; Seguin et al., 2005; Weiler et al., 2005; Evans, 2006; Fei et al., 2006; Yoon and Patel, 2006; Kuh et al., 2008; Sheikh et al., 2009). This is the first comparative study of the molecular biological response to cytokine treatment in cervical versus lumbar discs. This study was conducted to investigate the molecular biological response of degenerated human cervical and lumbar nucleus pulposus (NP) cells when treated with morphogens (rhBMP-2, TGF- $\beta 1$ ) that influence disc metabolism and phenotype, and to determine differences between degenerative cervical and lumbar discs.

\section{MATERIAL AND METHODS}

\section{Clinical materials}

Living degenerated disc specimens were obtained from 16 patients ( 8 cervical and 8 lumbar disc samples) who underwent discectomy for degenerative disc disease unresponsive to conservative therapy. After dissecting the disc space, a rectangular cut around the annulus fibrosus was made with a sharp knife, and using pituitary forceps, the disc was removed with the annulus and NP en block. After confirming the margin of the annulus and nucleus, only the NP was excised for this study. 
MRI (Magneton Vision 1.5T, Siemens, Erlangen, Germany) was performed on all patients. The PACS software and a PACS workstation (Centricity 2.0, General Electric Medical Systems, Milwaukee, WI, USA) were used to classify disc degeneration by an independent neurosurgeon and neuroradiologist not involved in the treatment. Disc degeneration was graded using routine T2-weighted MR images by the Pfirrmann grading system (Pfirrmann et al., 2001). Only Pfirrmann grades IV and V were included in this study. This study was approved by the Institutional Review Board (IRB) of Gangnam Severance Hospital, Yonsei University College of Medicine (No. 3-2010-0008).

\section{Isolation of disc cells and culture}

All reagents were purchased from GibcoBRL (Grand Island, NY, USA). During lumbar discectomy, intervertebral disc materials were excised, and as mentioned above, disc tissues were acquired from the nucleus pulposus and not from the annulus to ensure sample homogeneity. Tissues were dissected into small pieces and incubated in 5\% $\mathrm{CO}_{2} / 95 \%$ room air at $37^{\circ} \mathrm{C}$ in Dulbecco's modified Eagle's medium and in Ham's F-12 (DMEM/F-12) medium. To isolate nucleus pulposus cells, tissues were digested in DMEM/F-12 medium containing $0.2 \%$ protease (Sigma Chemical, St. Louis, MO, USA) for $1 \mathrm{~h}$, followed by $0.025 \%$ collagenase (Sigma) for $12 \mathrm{~h}$. Cells passaged no more than twice were used in the subsequent experiments. $\mathrm{NP}\left(3 \times 10^{4}\right.$ cells/well $)$ were grown as monolayer cultures for 6 days in DMEM/F-12 medium containing $10 \%$ fetal bovine serum (FBS), $10 \mathrm{U} / \mathrm{mL}$ penicillin, $10 \mu \mathrm{g} / \mathrm{mL}$ streptomycin, and $0.2 \mathrm{mM}$ L-glutamine. Primers to detect the mRNA expression of aggrecan, alkaline phosphatase, type I collagen, type II collagen, osteocalcin, and Sox9 were then constructed using complete mRNA sequences obtained from the National Center for Biotechnology Information. The forward and reverse primer sequences of all genes examined in this study are summarized in Table 1.

\begin{tabular}{|c|c|c|}
\hline & Primer & Sequence $\left(5^{\prime} \rightarrow 3^{\prime}\right)$ \\
\hline \multirow[t]{2}{*}{ 1. Aggrecan } & Forward & CTGCTTCCGAGGCATTTCAG \\
\hline & Reverse & CTTGGGTCACGATCCACTCC \\
\hline \multirow[t]{2}{*}{ 2. Alkaline phosphatase } & Forward & ATGGGATGGGTGTCTCCACA \\
\hline & Reverse & CCACGAAGGGGAACTTGTC \\
\hline \multirow{2}{*}{ 3. Type I collagen } & Forward & GTCGAGGGCCAAGACGAAG \\
\hline & Reverse & CAGATCACGTCATCGCACAAC \\
\hline \multirow[t]{2}{*}{ 4. Type II collagen } & Forward & GGTCTTGGTGGAAACTTTGCT \\
\hline & Reverse & GGTCCTTGCATTACTCCCAAC \\
\hline \multirow[t]{2}{*}{ 5. Osteocalcin } & Forward & CACTCCTCGCCCTATTGGC \\
\hline & Reverse & СССТCСТGCTTGGACACAAAG \\
\hline \multirow[t]{2}{*}{ 6. Sox9 } & Forward & AGCGAACGCACATCAAGAC \\
\hline & Reverse & GCTGTAGTGTGGGAGGTTGAA \\
\hline \multirow[t]{2}{*}{ 7. GAPDH* } & Forward & ATGGGGAAGGTGAAGGTCG \\
\hline & Reverse & GGGGTCATTGATGGCAACAATA \\
\hline
\end{tabular}

*GAPDH (glyceraldehyde-3-phosphate dehydrogenase) was used as a house keeping gene.

\section{Treatment with cytokines}

NP in each experimental group were cultured on a 6-well plate in an incubator $(5 \%$ $\mathrm{CO}_{2} / 95 \%$ room air at $37^{\circ} \mathrm{C}$ ) at $3 \times 10^{4}$ cells/well. When the cells were confluent, the medium was replaced with DMEM/F-12 medium containing 1\% FBS for starvation, $10 \mathrm{U} / \mathrm{mL}$ penicil- 
lin, $10 \mu \mathrm{g} / \mathrm{mL}$ streptomycin, $0.2 \mathrm{mM} \mathrm{L}$-glutamine, and $5 \mu \mathrm{g} / \mathrm{mL}$ vitamin C. Gene expression levels after each treatment with 2 morphogens (rhBMP-2 and TGF- $\beta 1$ ) were analyzed using real-time PCR (RT-PCR). The mRNA expression levels in cervical and lumbar NP cultures without cytokine treatment were compared and used as a baseline control according to the treatment group. NP were grown as a monolayer and treated with $100 \mathrm{ng} / \mathrm{mL}$ rhBMP-2 (R\&D System, Minneapolis, MN, USA) or $10 \mathrm{ng} / \mathrm{mL}$ TGF- $\beta 1$ (Invitrogen, Carlsbad, CA, USA) for 6 days. On day 3 , the culture medium was changed while maintaining the same concentration of rhBMP-2 and TGF- $\beta 1$ in each well.

\section{RT-PCR assay}

An ABI StepOnePlus (Applied Biosystems, Foster city, CA, USA) system that detects SYBR green fluorescent dye incorporated in double-stranded DNA was used for analysis. The $20-\mu \mathrm{L}$ reaction mixture contained $200 \mathrm{ng}$ cDNA (obtained by RT-PCR) and 5 pmol each primer (aggrecan, alkaline phosphatase, type I collagen, type II collagen, osteocalcin, or Sox9). Forty RT-PCR cycles were performed for denaturation $\left(95^{\circ} \mathrm{C}\right.$ for $\left.30 \mathrm{~s}\right)$, annealing, and elongation $\left(60^{\circ} \mathrm{C}\right.$ for $\left.60 \mathrm{~s}\right)$. To confirm amplification specificity, PCR products were subjected to melting curve analysis. Threshold cycles $\left(\mathrm{C}_{\mathrm{T}}\right)$ for the genes analyzed were normalized to glyceraldehyde phosphate dehydrogenase (GAPDH) expression. The mRNA expression levels in cervical and lumbar disc tissues are reported as a ratio (cervical/lumbar).

\section{Immunofluorescence staining with antibodies}

$\mathrm{NP}$ cells $\left(3 \times 10^{4}\right.$ cells/well) were grown as monolayer cultures in DMEM/F-12 medium containing $1 \% \mathrm{FBS}, 10 \mathrm{U} / \mathrm{mL}$ penicillin, $10 \mu \mathrm{g} / \mathrm{mL}$ streptomycin, $0.2 \mathrm{mM} \mathrm{L}$-glutamine, and $5 \mu \mathrm{g} /$ $\mathrm{mL}$ vitamin $\mathrm{C}$. The cultured cells were fixed with $100 \% \mathrm{EtOH}$ and then washed with $10 \mathrm{mM}$ PBS (Sigma). Monoclonal anti-aggrecan, anti-alkaline phosphatase, anti-type I collagen, anti-type II collagen, anti-osteocalcin, and anti-Sox 9 antibodies were applied respectively at $4^{\circ} \mathrm{C}$ overnight. After washing, secondary antibody conjugated with fluorescein isothiocyanate (FITC) was applied to the wells. The immunoreactivity of intervertebral disc cells for rhBMP-2 and TGF- $\beta 1$ were analyzed to check the chondrogenic activity. The wells were then rinsed, mounted and photographed using a fluorescence photomicroscope (NIKON Microphot-SA, Japan). For immunofluorescence, fluorochromes on the sections were excited using a 510-nm emission filter for green fluorescent protein, and a 580-nm emission filter for secondary antibody with FITC.

\section{Statistical analysis}

Intergroup comparisons were made using the Wilcoxon signed-rank test and the Mann-Whitney test. P $<0.05$ was considered to be statistically significant. All analyses were carried out using SPSS ver. 15.00 (SPSS, Inc., Chicago, IL, USA).

\section{RESULTS}

\section{Patient characteristics}

Degenerated cervical and lumbar discs (Pfirrmann grades IV and V) were obtained 
from 16 patients who underwent discectomy for degenerative disc disease. Discs were allocated to two groups: cervical disc (Pfirrmann grade IV/V; 5/3 patients) and lumbar disc (Pfirrmann grade IV/V; 5/3 patients). There was no statistical difference in age between the cervical $(53.4 \pm 15.7$ years $)$ and lumbar disc $(56.9 \pm 15.8$ years $)$ groups.

\section{Quantitation of mRNA levels}

We assayed the mRNA levels of aggrecan, alkaline phosphatase, type I collagen, type II collagen, osteocalcin, and Sox9. The mean values and standard deviations of all parameters studied are listed in Table 2. Baseline mRNA gene expression levels by $\mathrm{C}_{\mathrm{T}}$ mean in cervical and lumbar NP cells without cytokine treatment were not statistically different except for type I collagen. mRNA expression in the lumbar discs was significantly higher for type I collagen $(1.53$-fold) than in cervical discs (Table 2 and Figure $1 ; \mathrm{P}<0.05)$. The mRNA levels of aggrecan, alkaline phosphatase, type II collagen, osteocalcin, and Sox9 tended to be higher in lumbar discs (Figure 1).

\begin{tabular}{|c|c|c|c|c|c|c|c|c|c|c|c|c|c|c|c|c|}
\hline & \multicolumn{8}{|c|}{ Cervical } & \multicolumn{8}{|c|}{ Lumbar } \\
\hline & RQ & $\pm \mathrm{SD}$ & $\begin{array}{c}\mathrm{CT} \\
\text { mean }\end{array}$ & $\pm \mathrm{SD}$ & $\begin{array}{l}\Delta \mathrm{CT} \\
\text { mean }\end{array}$ & $\pm \mathrm{SD}$ & $\Delta \Delta \mathrm{CT}_{\mathrm{T}}$ & $\pm \mathrm{SD}$ & RQ & $\pm \mathrm{SD}$ & $\begin{array}{c}\mathrm{CT} \\
\text { mean }\end{array}$ & $\pm \mathrm{SD}$ & $\begin{array}{l}\Delta \mathrm{CT} \\
\text { mean }\end{array}$ & $\pm \mathrm{SD}$ & $\Delta \Delta \mathrm{CT}_{\mathrm{T}}$ & $\pm \mathrm{SD}$ \\
\hline $\begin{array}{l}\text { Aggrecan without } \\
\text { cytokines }\end{array}$ & 1.00 & - & 27.06 & 2.68 & 6.36 & 3.54 & - & - & 1.00 & - & 35.03 & 6.43 & 5.49 & 5.21 & - & - \\
\hline Aggrecan with rhBMP-2 & 3.33 & 0.94 & 25.15 & 3.01 & 4.68 & 3.31 & -1.69 & 0.39 & 2.50 & 0.58 & 33.21 & 6.15 & 4.20 & 5.20 & -1.29 & 0.34 \\
\hline Aggrecan with TGF- $\beta 1$ & 2.80 & 0.87 & 25.05 & 3.36 & 4.94 & 3.59 & -1.42 & 0.46 & 2.14 & 0.51 & 32.89 & 6.44 & 4.43 & 5.17 & -1.06 & 0.36 \\
\hline $\begin{array}{l}\text { Alkaline phosphatase } \\
\text { without cytokines }\end{array}$ & 1.00 & - & 30.78 & 3.09 & 9.69 & 1.90 & - & - & 1.00 & - & 35.85 & 5.05 & 6.30 & 4.51 & - & - \\
\hline $\begin{array}{l}\text { Alkaline phosphatase } \\
\text { with rhBMP-2 }\end{array}$ & 2.77 & 0.74 & 28.22 & 2.01 & 8.26 & 1.99 & -1.42 & 0.38 & 2.78 & 0.72 & 33.87 & 4.86 & 4.86 & 4.37 & -1.44 & 0.33 \\
\hline $\begin{array}{l}\text { Alkaline phosphatase } \\
\text { with TGF- } \beta 1\end{array}$ & 2.32 & 1.04 & 28.52 & 2.00 & 8.57 & 1.90 & -1.12 & 0.54 & 2.16 & 0.37 & 33.67 & 4.83 & 5.21 & 4.65 & -1.09 & 0.25 \\
\hline $\begin{array}{l}\text { Type I collagen without } \\
\text { cytokines }\end{array}$ & 1.00 & - & $20.96 \dagger$ & 2.74 & -1.62 & 4.93 & - & - & 1.00 & - & $31.99 \dagger$ & 7.52 & 2.45 & 3.87 & - & - \\
\hline $\begin{array}{l}\text { Type I collagen with } \\
\text { rhBMP-2 }\end{array}$ & $2.90^{*}$ & 1.17 & 18.66 & 1.63 & -3.07 & 5.27 & -1.44 & 0.55 & 1.87 & 0.38 & 30.58 & 7.24 & 1.57 & 3.86 & -0.88 & 0.29 \\
\hline $\begin{array}{l}\text { Type I collagen with } \\
\text { TGF- } \beta 1\end{array}$ & 2.67 & 1.14 & 18.65 & 2.13 & -2.92 & 4.95 & -1.30 & 0.64 & 2.38 & 1.10 & 29.76 & 7.26 & 1.30 & 3.79 & -1.15 & 0.57 \\
\hline $\begin{array}{l}\text { Type II collagen without } \\
\text { cytokines }\end{array}$ & 1.00 & - & 31.96 & 3.75 & 9.97 & 3.56 & - & - & 1.00 & - & 36.07 & 2.49 & 6.52 & 6.42 & - & - \\
\hline $\begin{array}{l}\text { Type II collagen with } \\
\text { rhBMP-2 }\end{array}$ & $3.52 *$ & 0.81 & 29.53 & 2.77 & 8.19 & 3.49 & -1.78 & 0.32 & 2.53 & 0.37 & 34.20 & 2.56 & 5.19 & 6.40 & -1.33 & 0.20 \\
\hline $\begin{array}{l}\text { Type II collagen with } \\
\text { TGF- } \beta 1\end{array}$ & 2.43 & 0.76 & 29.91 & 3.54 & 8.76 & 3.59 & -1.21 & 0.50 & 2.71 & 0.87 & 33.61 & 2.46 & 5.15 & 6.64 & -1.37 & 0.48 \\
\hline $\begin{array}{l}\text { Osteocalcin without } \\
\text { cytokines }\end{array}$ & 1.00 & - & 32.83 & 1.58 & 11.30 & 4.14 & - & - & 1.00 & - & 35.91 & 3.31 & 6.37 & 5.86 & - & - \\
\hline $\begin{array}{l}\text { Osteocalcin with } \\
\text { rhBMP-2 }\end{array}$ & 2.30 & 0.98 & 31.35 & 1.23 & 10.21 & 4.38 & -1.09 & 0.61 & 2.57 & 1.09 & 34.12 & 3.26 & 5.11 & 5.51 & -1.26 & 0.56 \\
\hline Osteocalcin with TGF- $\beta 1$ & 1.97 & 0.59 & 31.12 & 1.18 & 10.37 & 4.18 & -0.93 & 0.42 & 2.06 & 0.80 & 33.85 & 3.02 & 5.39 & 5.57 & -0.97 & 0.45 \\
\hline Sox9 without cytokines & 1.00 & - & 26.61 & 2.76 & 5.92 & 2.53 & - & - & 1.00 & - & 33.28 & 5.83 & 3.73 & 1.71 & - & - \\
\hline Sox9 with rhBMP-2 & 2.27 & 0.54 & 25.24 & 3.46 & 4.77 & 2.57 & -1.15 & 0.35 & 2.41 & 0.60 & 31.51 & 5.82 & 2.50 & 1.59 & -1.24 & 0.31 \\
\hline Sox9 with TGF- $\beta 1$ & 2.34 & 0.53 & 24.84 & 3.20 & 4.73 & 2.49 & -1.19 & 0.35 & 2.27 & 0.58 & 30.93 & 5.43 & 2.47 & 2.08 & -1.13 & 0.44 \\
\hline
\end{tabular}

$\mathrm{RQ}=$ relative quantification; $\mathrm{SD}=$ standard deviation; $\mathrm{C}_{\mathrm{T}}=$ threshold cycle. $\dagger \mathrm{P}<0.05$ for cervical $v s$ lumbar disc without cytokine treatment. $* \mathrm{P}<0.05$ for cervical $v$ lumbar disc after cytokine treatment. Significance was assessed using the Mann-Whitney U-test. 


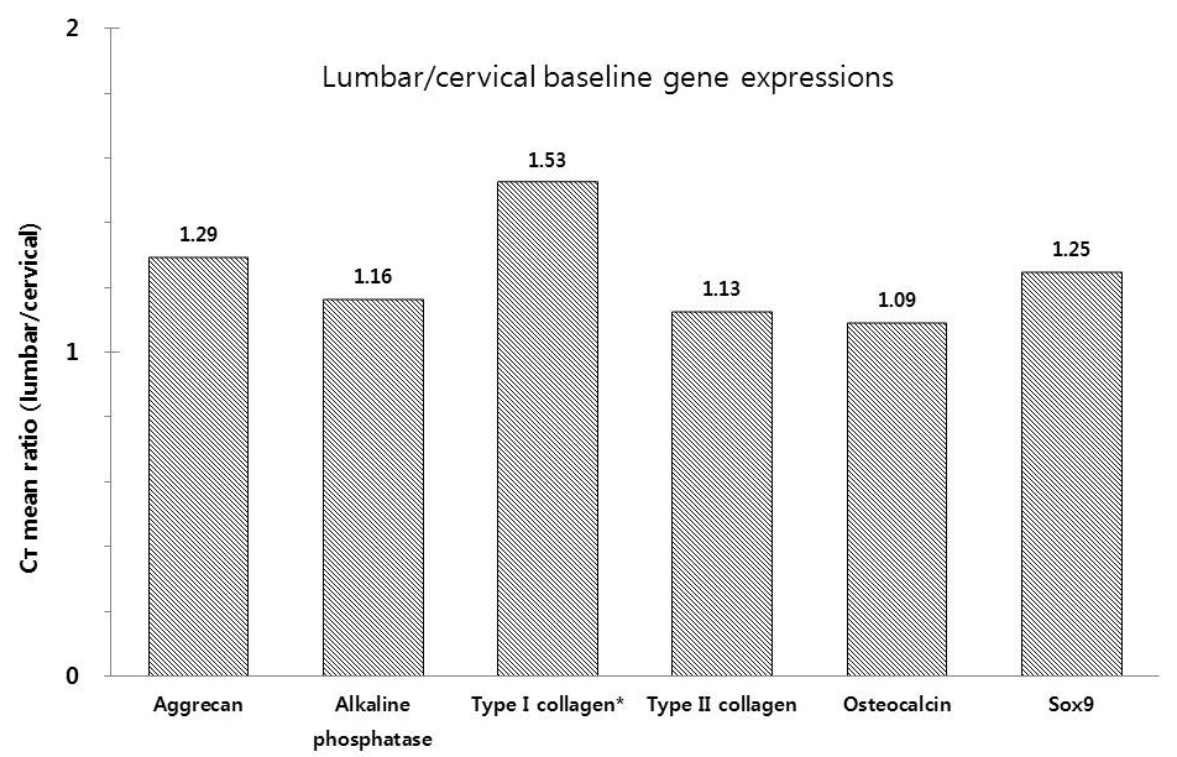

Figure 1. Threshold cycle $\left(\mathrm{C}_{\mathrm{T}}\right)$ mean ratio between lumbar and cervical disc cells (lumbar/cervical) for mRNA levels of aggrecan, alkaline phosphatase, type I collagen, type II collagen, osteocalcin, and Sox 9 without cytokine treatment. $* \mathrm{P}<0.05$ between cervical and lumbar comparisons.

After rhBMP-2 and TGF- $\beta 1$ treatment, mRNA levels by relative quantification (RQ) of aggrecan, alkaline phosphatase, type I collagen, type II collagen, osteocalcin, and Sox9 were statistically increased in cervical and lumber discs when compared to groups without treatment (Tables 2 and 3; Figure 2; $\mathrm{P}<0.01$ ). Following rhBMP-2 treatment, mRNA expression of type I collagen (RQ for cervical/lumbar: 2.90/1.87) and type II collagen (RQ for cervical/lumbar: 3.52/2.53) demonstrated significant differences between cervical and lumbar discs with higher expression in the cervical discs (Tables 2 and 3; Figure 2; $\mathrm{P}<0.05$ ). The mRNA levels of aggrecan, alkaline phosphatase, osteocalcin, and Sox9 were not statistically different (Tables 2 and 3; Figure 2). Following TGF- $\beta 1$ treatment, mRNA levels of aggrecan, alkaline phosphatase, type I collagen, type II collagen, osteocalcin, and Sox9 were not statistically different between cervical and lumbar discs (Tables 2 and 3; Figure 2).

Table 3. mRNA expression after cytokine treatment compared to groups without treatment.

\begin{tabular}{|c|c|c|c|c|c|c|c|c|}
\hline & \multicolumn{4}{|c|}{ Cervical } & \multicolumn{4}{|c|}{ Lumbar } \\
\hline & \multicolumn{2}{|c|}{ rhBMP-2 } & \multicolumn{2}{|c|}{ TGF- $\beta 1$} & \multicolumn{2}{|c|}{ rhBMP-2 } & \multicolumn{2}{|c|}{ TGF- $\beta 1$} \\
\hline & RQ & $\pm \mathrm{SD}$ & RQ & $\pm \mathrm{SD}$ & RQ & $\pm \mathrm{SD}$ & RQ & $\pm \mathrm{SD}$ \\
\hline Aggrecan & 3.33 & 0.94 & 2.80 & 0.87 & 2.50 & 0.58 & 2.14 & 0.51 \\
\hline Alkaline phosphatase & 2.77 & 0.74 & 2.32 & 1.04 & 2.78 & 0.72 & 2.16 & 0.37 \\
\hline Type I collagen & $2.90 *$ & 1.17 & 2.67 & 1.14 & $1.87 *$ & 0.38 & 2.38 & 1.10 \\
\hline Type II collagen & $3.52 *$ & 0.81 & 2.43 & 0.76 & $2.53 *$ & 0.37 & 2.71 & 0.87 \\
\hline Osteocalcin & 2.30 & 0.98 & 1.97 & 0.59 & 2.57 & 1.09 & 2.06 & 0.80 \\
\hline Sox 9 & 2.27 & 0.54 & 2.34 & 0.53 & 2.41 & 0.60 & 2.27 & 0.58 \\
\hline
\end{tabular}

$\mathrm{RQ}=$ relative quantification; $\mathrm{SD}=$ standard deviation. $* \mathrm{P}<0.05$ for cervical $v s$ lumbar disc after cytokine treatment. Significance was assessed using the Mann-Whitney U-test. 


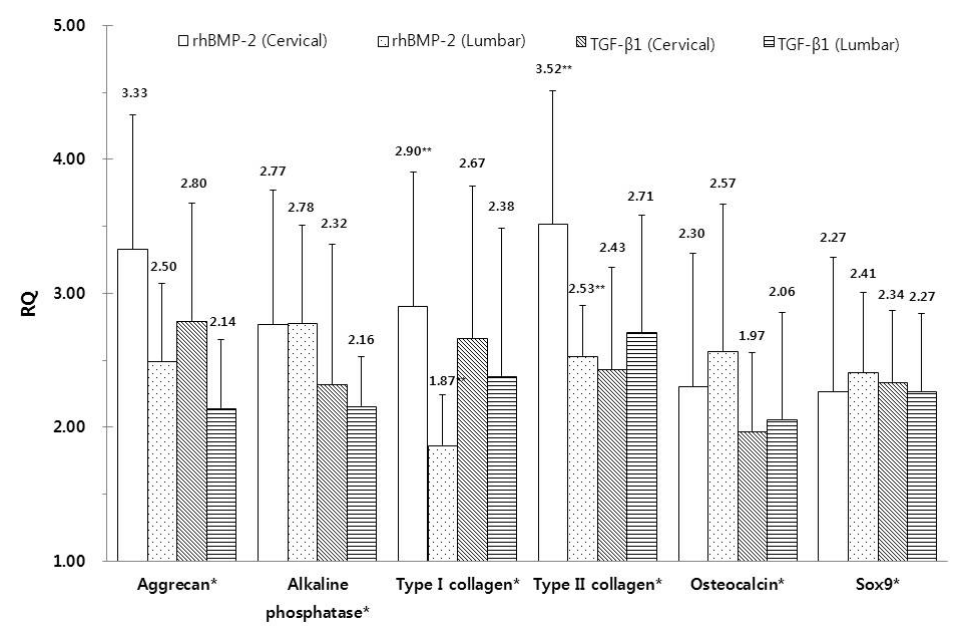

Figure 2. mRNA level ratios between groups without treatment and with cytokine treatment by relative quantification (RQ). The mRNA levels of aggrecan, alkaline phosphatase, type I collagen, type II collagen, osteocalcin, and Sox 9 with cytokine (rhBMP-2, TGF- $\beta 1$ ) treatment were assayed in cervical and lumbar disc cells. ${ }^{*} \mathrm{P}<0.01$ between groups without treatment and with cytokine treatment. ${ }^{*} \mathrm{P}<0.05$ between cervical and lumbar after rhBMP-2 treatment.

\section{Immunofluorescence reactivity}

The average numbers of immunofluorescence-positive cells for all proteins are listed in Table 4. The protein immunoreactivity of aggrecan, alkaline phosphatase, type I collagen, type II collagen, osteocalcin, and Sox9, with and without cytokine, also showed similar results as mRNA expression. After rhBMP-2 and TGF- $\beta 1$ treatment, the average numbers of immunofluorescence-positive cells for aggrecan, alkaline phosphatase, type I collagen, type II collagen, osteocalcin, and Sox9 were increased in cervical (Figure 3) and lumbar discs (Figure 4) when compared to groups without treatment (Table 4).

Table 4. Average number of immunofluorescence-positive-stained cell.

\begin{tabular}{|c|c|c|c|c|}
\hline & \multicolumn{2}{|c|}{ Cervical } & \multicolumn{2}{|c|}{ Lumbar } \\
\hline & Cell numbers & $\pm \mathrm{SD}$ & Cell numbers & $\pm \mathrm{SD}$ \\
\hline Aggrecan without cytokines & 17.00 & 12.33 & 7.00 & 1.63 \\
\hline Aggrecan with rhBMP-2 & 77.25 & 13.60 & 28.00 & 11.17 \\
\hline Aggrecan with TGF- $\beta 1$ & 44.00 & 12.91 & 13.50 & 2.65 \\
\hline Alkaline phosphatase without cytokines & 30.50 & 12.87 & 10.75 & 4.86 \\
\hline Alkaline phosphatase with rhBMP-2 & 68.50 & 10.85 & 20.50 & 9.68 \\
\hline Alkaline phosphatase with TGF- $\beta 1$ & 50.50 & 22.66 & 15.50 & 6.61 \\
\hline Type I collagen without cytokines & 21.00 & 0.82 & 4.25 & 1.50 \\
\hline Type I collagen with rhBMP-2 & 67.25 & 8.26 & 16.75 & 9.43 \\
\hline Type I collagen with TGF- $\beta 1$ & 47.25 & 13.45 & 8.25 & 3.50 \\
\hline Type II collagen without cytokines & 35.25 & 15.84 & 6.50 & 3.11 \\
\hline Type II collagen with rhBMP-2 & 84.50 & 23.25 & 13.75 & 1.89 \\
\hline Type II collagen with TGF- $\beta 1$ & 57.75 & 9.74 & 15.00 & 8.29 \\
\hline Osteocalcin without cytokines & 22.25 & 5.56 & 4.00 & 2.16 \\
\hline Osteocalcin with rhBMP-2 & 48.50 & 16.13 & 12.50 & 1.73 \\
\hline Osteocalcin with TGF- $\beta 1$ & 38.50 & 20.70 & 7.25 & 1.89 \\
\hline Sox9 without cytokines & 39.00 & 24.68 & 3.00 & 2.16 \\
\hline Sox9 with rhBMP-2 & 61.00 & 13.19 & 10.75 & 3.30 \\
\hline Sox9 with TGF- $\beta 1$ & 67.00 & 12.83 & 8.00 & 3.37 \\
\hline
\end{tabular}

$\mathrm{SD}=$ standard deviation. 
1
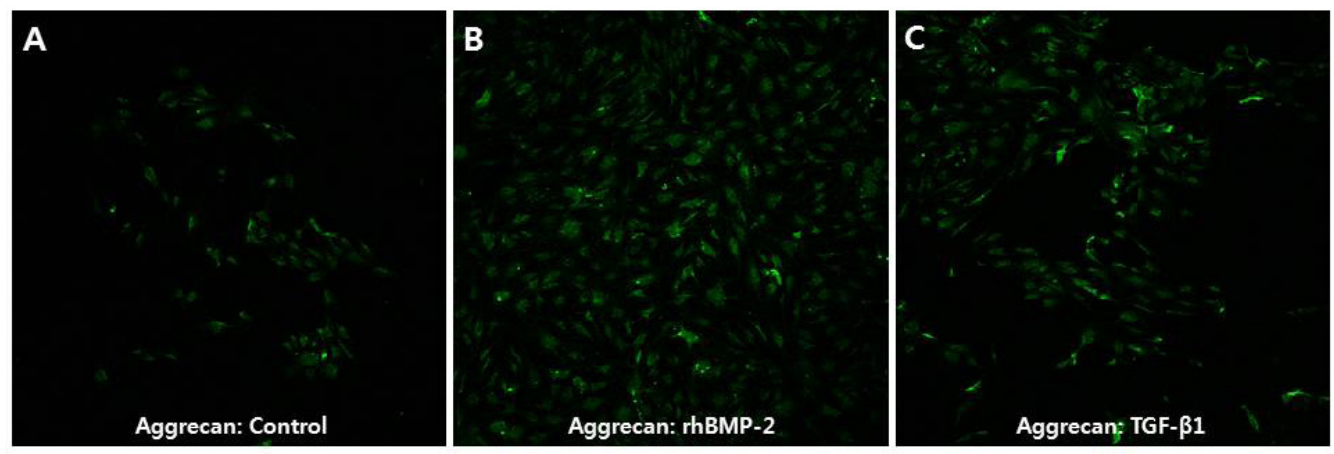

\section{2}
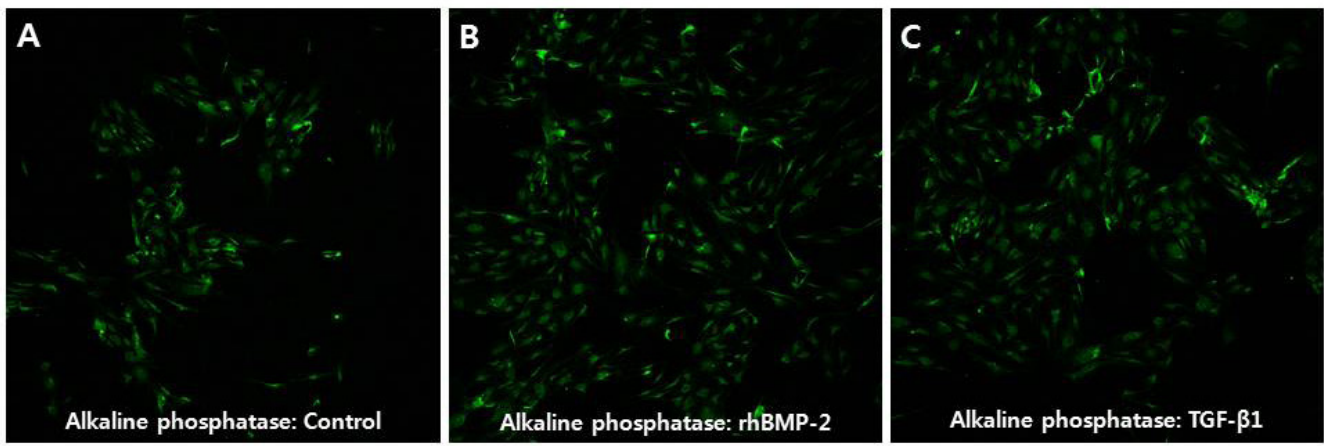

\section{3}

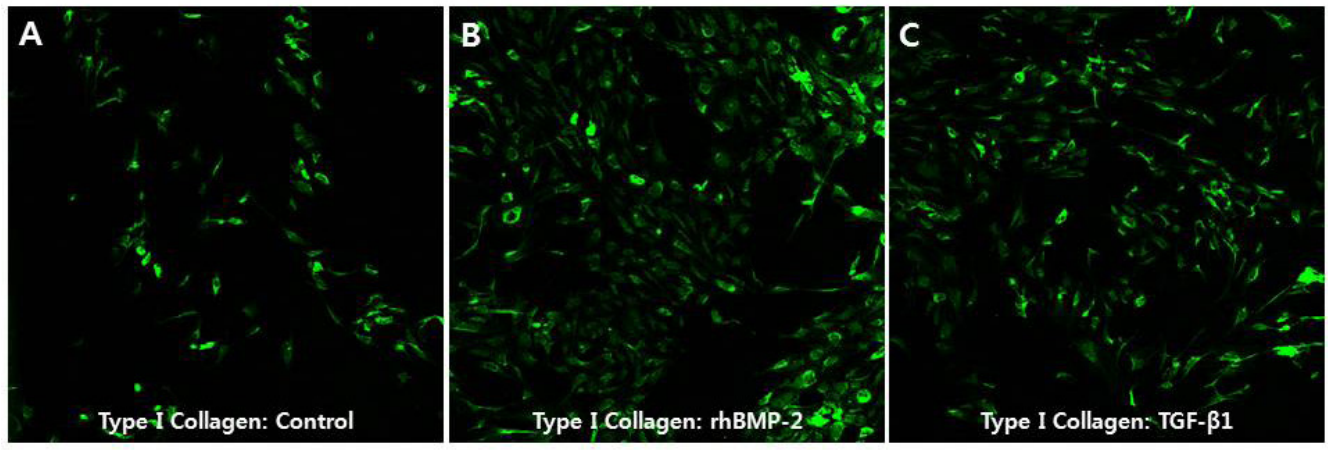

Figure 3. Immunostaining of human intervertebral disc cells for aggrecan (1), alkakine phosphatase (2), type I collagen (3), type II collagen (4), osteocalcin (5), and Sox9 (6) in cervical disc in controls (A) and after rhBMP-2 (B), and TGF- $\beta 1$ treatment $(\mathbf{C})$.

Continued on next page 
Figure 3. Continued.

4
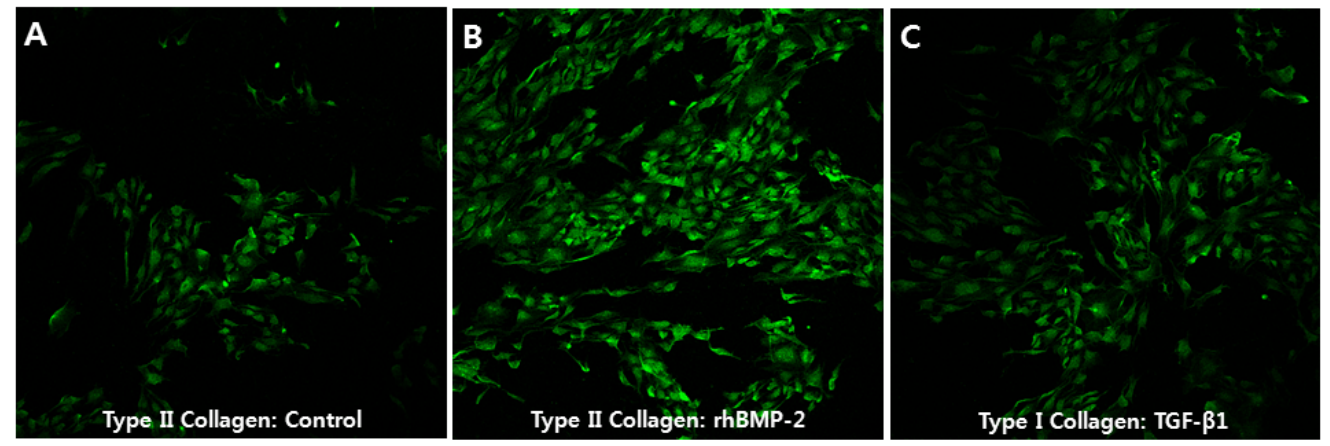

5

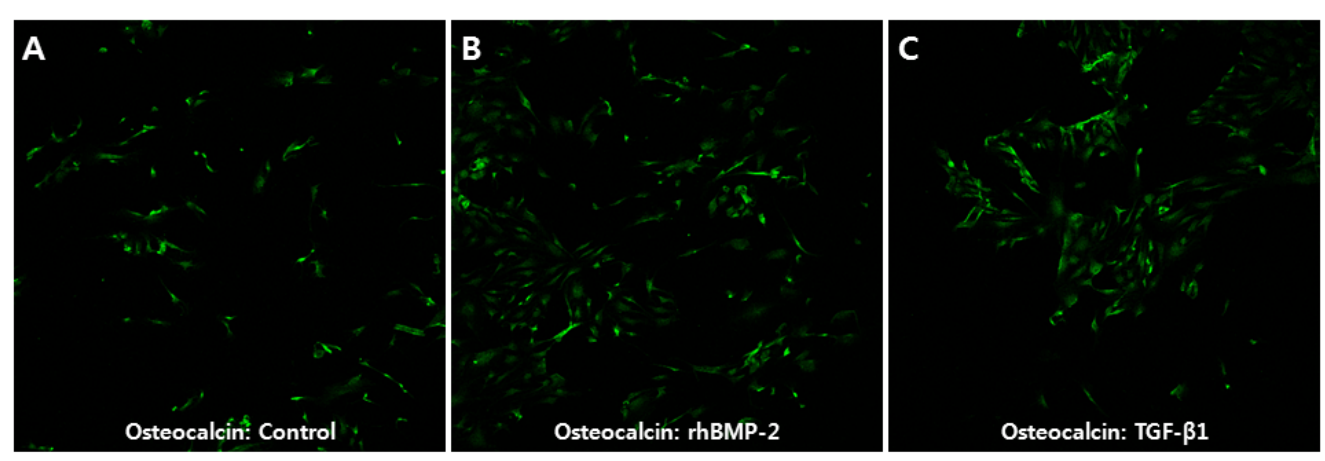

6
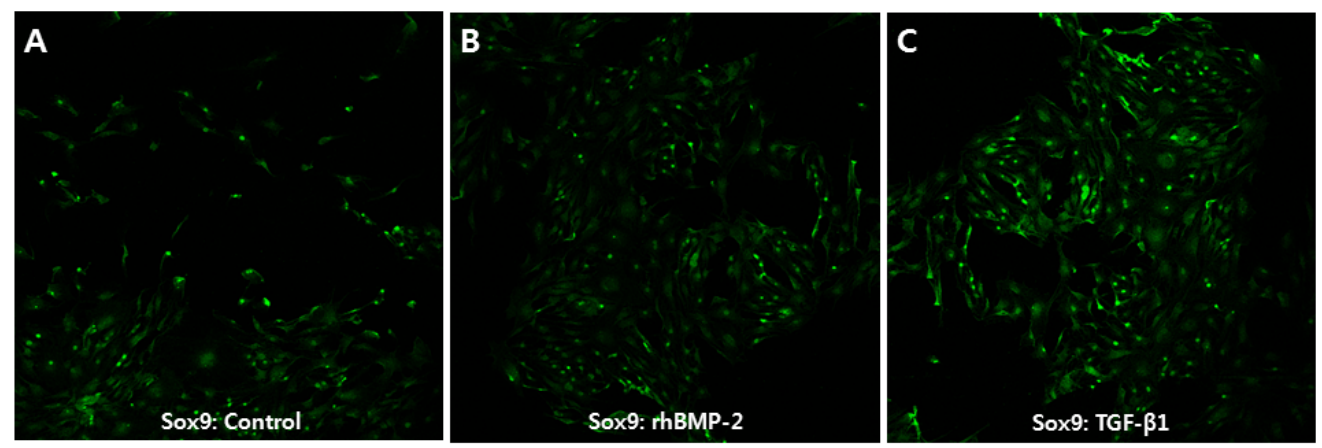

Genetics and Molecular Research 12 (1): 838-851 (2013) 
1
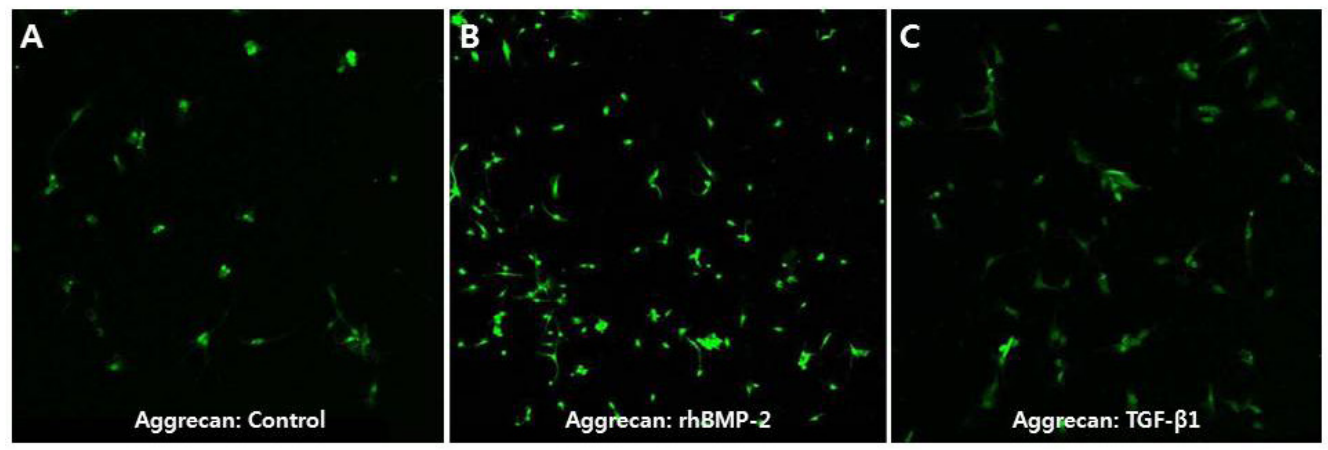

2
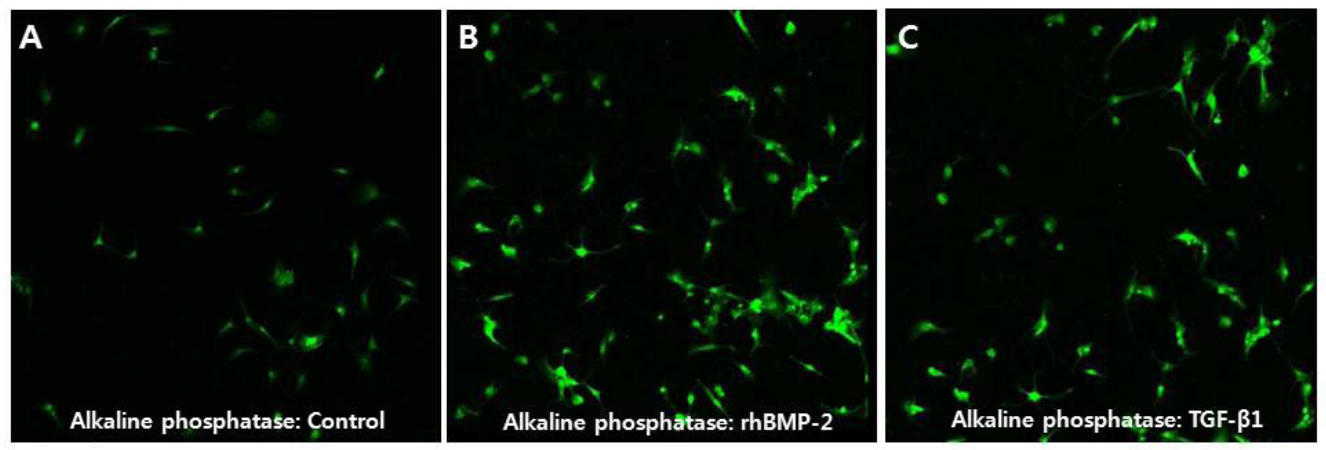

3

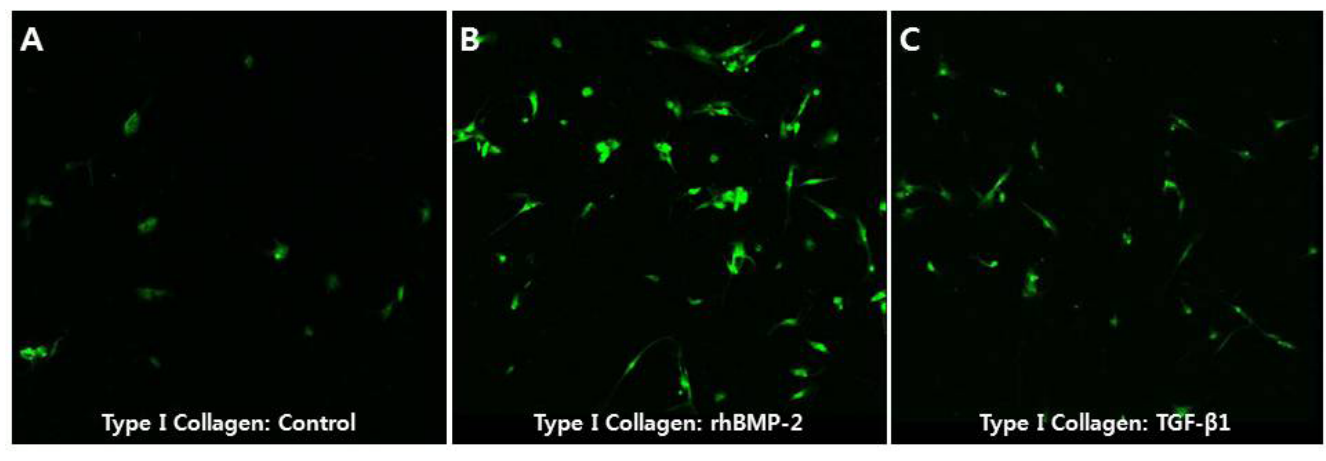

Figure 4. Immunostaining of human intervertebral disc cells for aggrecan (1), alkaline phosphatase (2), type I collagen (3), type II collagen (4), osteocalcin (5), and Sox9 (6) in lumbar disc in controls (A) and after rhBMP-2 (B) and TGF- $\beta 1$ treatment $(\mathbf{C})$.

Continued on next page 
Figure 4. Continued.

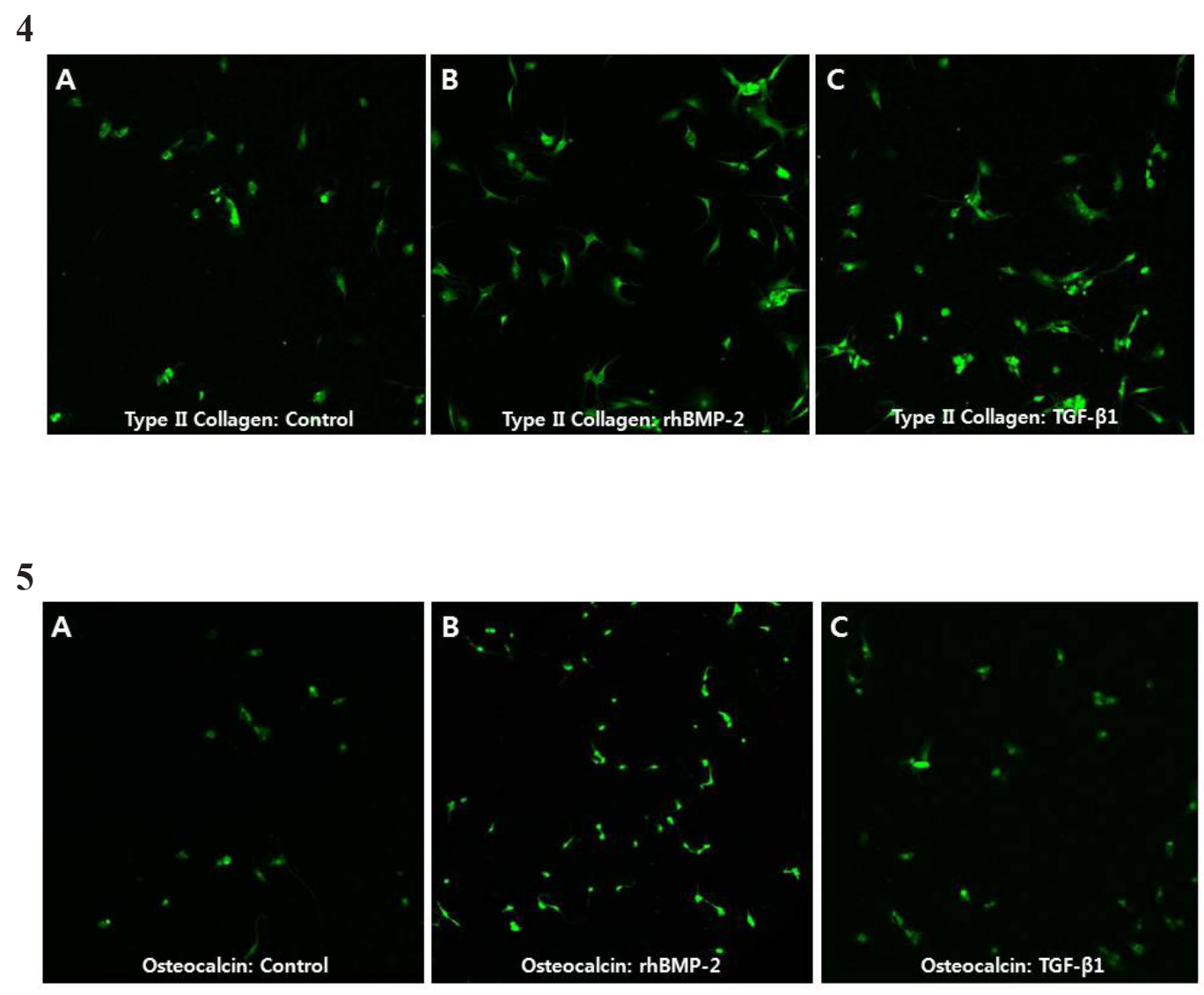

6

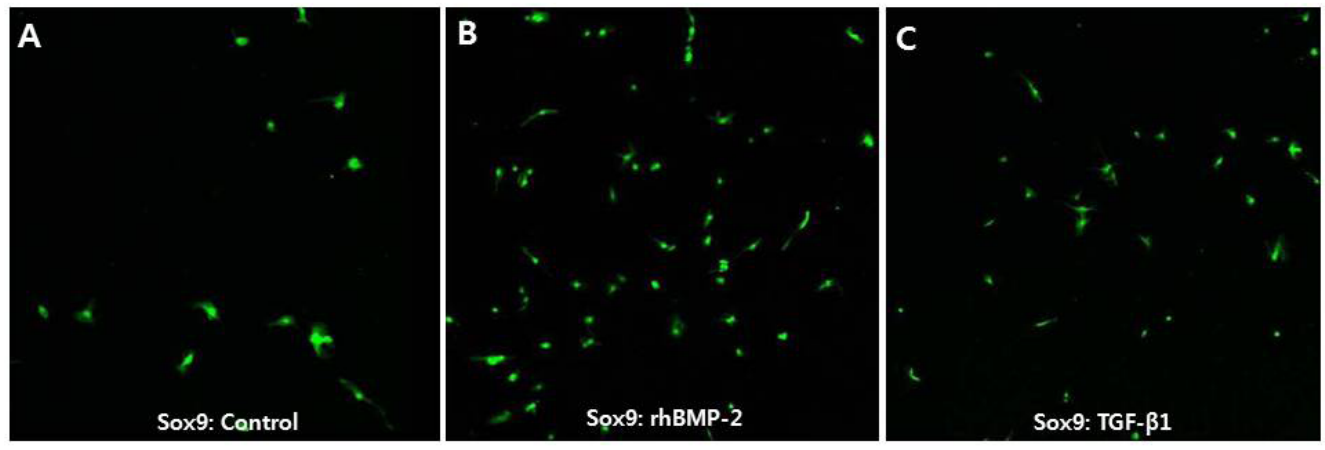

Genetics and Molecular Research 12 (1): 838-851 (2013) 


\section{DISCUSSION}

Human beings have had back pain throughout recorded history, but not neck pain, so disc treatments usually focus on lumbar rather than cervical discs (Waddell, 1996; Feuerstein et al., 2004; Sobajima et al., 2008; Genevay et al., 2009; Kuh et al., 2008, 2009; Park et al., 2011). In the current study, differences between cervical and lumbar disc degeneration at the gene expression level were investigated. The purpose of the current study was to investigate and compare the expression of matrix-associated genes in cervical and lumbar discs when degenerative changes have occurred and to compare responses following cytokine treatment.

The results of the current study indicate that cervical and lumbar discs have similar gene expression patterns in living degenerated human discs. A prior study by Scott et al. (1994) reported that the collagen content of the NP was highest in cervical discs and lowest in lumbar discs (Longo et al., 2006). The reason cervical discs have more collagen than lumbar discs may be that the cell number is much greater in cervical discs or that gene expression is higher in cervical discs. The current results suggest that cervical collagen genes are more actively expressed than in lumbar discs in a similar degenerative state.

This study also attempted to address whether there are differences between cervical and lumbar discs in response to molecular treatment. Following rhBMP-2 and TGF- $\beta 1$ treatment, mRNA levels of aggrecan, alkaline phosphatase, type I collagen, type II collagen, osteocalcin, and Sox9 were statistically increased in both cervical and lumbar discs. Molecular therapies for disc degeneration have been devised based on phenotypic changes in degenerated discs (Yoon and Patel, 2006). In general, four different classes of molecules are currently being investigated: anti-catabolics, mitogens, morphogens, and intracellular regulators (Tim et al., 2003; Yoon et al., 2004; Seguin et al., 2005; Weiler et al., 2005; Evans, 2006; Fei et al., 2006; Yoon and Patel, 2006; Kuh et al., 2008; Park et al., 2011). However, molecular therapy trials have been conducted on individual candidates and only at one location among the cervical, thoracic, and lumbar discs (Tim et al., 2003; Yoon et al., 2004; Seguin et al., 2005; Weiler et al., 2005; Evans, 2006; Fei et al., 2006; Yoon and Patel, 2006; Kuh et al., 2008; Sheikh et al., 2009). This is the first study to compare responses to molecular therapies between cervical and lumbar disc cells. Following rhBMP-2 treatment, mRNA expression of type I and II collagens was significantly different between cervical and lumbar disc cells, with cervical disc cells demonstrating higher gene expression. The mRNA levels of aggrecan, alkaline phosphatase, osteocalcin, and Sox9 were not statistically different for cervical versus lumbar discs.

When comparing baseline gene expression without cytokine treatment, we can conclude that collagen gene expression is more active in cervical disc cells than in lumbar disc cells, with or without treatment. Although many anatomic differences exist between the cervical and lumbar spine, differences in collagen gene expression may be associated with a lower rate of neck pain compared with back pain. However, there were no statistical differences in mRNA expression for all matrix-associated genes between the cervical and lumbar disc cells following TGF- $\beta 1$ treatment. This suggests that matrix-associated gene responses can differ according to molecular therapy. From the current study, we conclude that the general response to molecular therapy in cervical and lumbar discs is similar, and that a healthy disc at either location can be used for cell transplantation therapy to other discs. As an example, less degenerated cervical nucleus pulposus cells could be transplanted to a lumbar disc after culture for disc therapy. 
This study has several limitations that require consideration. The sample size was small and only focused on matrix-associated genes. Various pro-inflammatory cytokines (TNF- $\alpha$, IL-1 $\beta$, IL-6, IL-1 $\alpha$, nitric oxide, and prostaglandin $\mathrm{E}_{2}$, among others) are upregulated during disc degeneration (Yoon and Patel, 2006; Zhao et al., 2007; Rutges et al., 2008; Fassett et al., 2009; Millward-Sadler et al., 2009). To determine the exact differences between cervical and lumbar disc degeneration, studies including these pro-inflammatory cytokines are required. Additionally, only two morphogens (rhBMP-2 and TGF- $\beta 1$ ) were studied. Athough rhBMP- 2 and TGF- $\beta 1$ are the most commonly used morphogens in molecular therapy for disc regeneration, different classes of molecules are also being investigated, namely, anti-catabolics, mitogens, morphogens, and intracellular regulators (Tim et al., 2003; Yoon et al., 2004; Seguin et al., 2005; Weiler et al., 2005; Evans, 2006; Yoon and Patel, 2006; Fei et al., 2006; Kuh et al., 2008; Park et al., 2011). Further study with various treatment molecules is needed to adequately compare responses to molecular therapy between cervical and lumbar discs.

In spite of these limitations, our results demonstrate that degenerated cervical and lumbar disc cells have similar gene expression patterns during degeneration, with the exception of type I collagen. Additionally, collagen gene expression is also associated with differences in molecular therapy response between cervical and lumbar discs. In general, cervical and lumbar discs demonstrated a similar degenerative pattern and similar molecular therapy responses.

\section{ACKNOWLEDGMENTS}

Research supported by a Faculty Research Grant of Yonsei University College of Medicine for 2010 (Grant \#6-2010-0106).

\section{REFERENCES}

Adam M and Deyl Z (1984). Degenerated annulus fibrosus of the intervertebral disc contains collagen type II. Ann. Rheum. Dis. 43: 258-263.

Antoniou J, Goudsouzian NM, Heathfield TF, Winterbottom N, et al. (1996a). The human lumbar endplate. Evidence of changes in biosynthesis and denaturation of the extracellular matrix with growth, maturation, aging, and degeneration. Spine 21: 1153-1161.

Antoniou J, Steffen T, Nelson F, Winterbottom N, et al. (1996b). The human lumbar intervertebral disc: evidence for changes in the biosynthesis and denaturation of the extracellular matrix with growth, maturation, ageing, and degeneration. J. Clin. Invest. 98: 996-1003.

Diefenderfer DL and Brighton CT (2000). Microvascular pericytes express aggrecan message which is regulated by BMP2. Biochem. Biophys. Res. Commun. 269: 172-178.

Evans C (2006). Potential biologic therapies for the intervertebral disc. J. Bone Joint Surg. Am. 88 (Suppl 2): 95-98.

Fassett DR, Kurd MF and Vaccaro AR (2009). Biologic solutions for degenerative disk disease. J. Spinal Disord. Tech. 22: 297-308.

Fei QM, Jiang XX, Chen TY, Li J, et al. (2006). Changes with age and the effect of recombinant human BMP-2 on proteoglycan and collagen gene expression in rabbit anulus fibrosus cells. Acta Biochim. Biophys. Sin. 38: 773-779.

Feuerstein M, Marcus SC and Huang GD (2004). National trends in nonoperative care for nonspecific back pain. Spine J. 4: 56-63.

Genevay S, Finckh A, Mezin F, Tessitore E, et al. (2009). Influence of cytokine inhibitors on concentration and activity of MMP-1 and MMP-3 in disc herniation. Arthritis Res. Ther. 11: R169.

Kuh SU, Zhu Y, Li J, Tsai KJ, et al. (2008). Can TGF-beta1 and rhBMP-2 act in synergy to transform bone marrow stem cells to discogenic-type cells? Acta Neurochir. 150: 1073-1079.

Kuh SU, Zhu Y, Li J, Tsai KJ, et al. (2009). A comparison of three cell types as potential candidates for intervertebral disc therapy: annulus fibrosus cells, chondrocytes, and bone marrow derived cells. Joint Bone Spine 76: 70-74.

Longo UG, Ripalda P, Denaro V and Forriol F (2006). Morphologic comparison of cervical, thoracic, lumbar intervertebral 
discs of cynomolgus monkey (Macaca fascicularis). Eur. Spine J. 15: 1845-1851.

Millward-Sadler SJ, Costello PW, Freemont AJ and Hoyland JA (2009). Regulation of catabolic gene expression in normal and degenerate human intervertebral disc cells: implications for the pathogenesis of intervertebral disc degeneration. Arthritis Res. Ther. 11: R65.

Park JY, Kuh SU, Park HS and Kim KS (2011). Comparative expression of matrix-associated genes and inflammatory cytokines-associated genes according to disc degeneration: analysis of living human nucleus pulposus. J. Spinal Disord. Tech 24: 352-357.

Peng B, Hao J, Hou S, Wu W, et al. (2006). Possible pathogenesis of painful intervertebral disc degeneration. Spine 31: 560-566.

Pfirrmann CW, Metzdorf A, Zanetti M, Hodler J, et al. (2001). Magnetic resonance classification of lumbar intervertebral disc degeneration. Spine 26: 1873-1878.

Rutges JP, Kummer JA, Oner FC, Verbout AJ, et al. (2008). Increased MMP-2 activity during intervertebral disc degeneration is correlated to MMP-14 levels. J. Pathol. 214: 523-530.

Scott JE, Bosworth TR, Cribb AM and Taylor JR (1994). The chemical morphology of age-related changes in human intervertebral disc glycosaminoglycans from cervical, thoracic and lumbar nucleus pulposus and annulus fibrosus. J. Anat. 184: 73-82.

Seguin CA, Pilliar RM, Roughley PJ and Kandel RA (2005). Tumor necrosis factor-alpha modulates matrix production and catabolism in nucleus pulposus tissue. Spine 30: 1940-1948.

Sheikh H, Zakharian K, De La Torre RP, Facek C, et al. (2009). In vivo intervertebral disc regeneration using stem cellderived chondroprogenitors. J. Neurosurg. Spine 10: 265-272.

Sobajima S, Vadala G, Shimer A, Kim JS, et al. (2008). Feasibility of a stem cell therapy for intervertebral disc degeneration. Spine J. 8: 888-896.

Tim YS, Su KK, Li J, Soo PJ, et al. (2003). The effect of bone morphogenetic protein-2 on rat intervertebral disc cells in vitro. Spine 28: 1773-1780.

Waddell G (1996). Low back pain: a twentieth century health care enigma. Spine 21: 2820-2825.

Weiler C, Nerlich AG, Bachmeier BE and Boos N (2005). Expression and distribution of tumor necrosis factor alpha in human lumbar intervertebral discs: a study in surgical specimen and autopsy controls. Spine 30: 44-53.

Yoon ST and Patel NM (2006). Molecular therapy of the intervertebral disc. Eur. Spine J. 15 (Suppl 3): S379-S388.

Yoon ST, Park JS, Kim KS, Li J, et al. (2004). ISSLS prize winner: LMP-1 upregulates intervertebral disc cell production of proteoglycans and BMPs in vitro and in vivo. Spine 29: 2603-2611.

Zhao CQ, Wang LM, Jiang LS and Dai LY (2007). The cell biology of intervertebral disc aging and degeneration. Ageing Res. Rev. 6: 247-261. 